\title{
Influence of the rain gauge network on the performance of a hydrological lumped model applied at different basin scales
}

\section{Influência da rede pluviométrica no desempenho de um modelo hidrológico concentrado aplicado em diferentes escalas de bacias}

\author{
Stefany Correia de Paula ${ }^{1}$, Rutineia Tassi ${ }^{1}$, Daniel Gustavo Allasia Piccilli ${ }^{1}$ and Francisco Lorenzini Neto ${ }^{2}$ \\ ${ }^{1}$ Universidade Federal de Santa Maria, Santa Maria, RS, Brasil \\ ${ }^{2}$ Instituto Federal Sul-rio-grandense, Santa Maria, RS, Brasil \\ E-mails: stefanycorreia07@gmail.com (SCP), rutineia@gmail.com (RT), dallasia@gmail.com (DGAP), f.lorenzinix@gmail.com (FLN)
}

Received: February 08, 2018 - Revised: June 12, 2018 - Aceppted: August 06, 2018

\begin{abstract}
In this study was evaluated the influence of the rainfall monitoring network density and distribution on the result of rainfall-runoff daily simulations of a lumped model (IPH II) considering basins with different drainage scales: Turvo River $\left(1,540 \mathrm{~km}^{2}\right)$, Ijuí River $\left(9,462 \mathrm{~km}^{2}\right)$, Jacuí River $\left(38,700 \mathrm{~km}^{2}\right)$ and Upper Uruguay $\left(61,900 \mathrm{~km}^{2}\right)$. For this purpose, four rain gauge coverage scenarios were developed: (I) 100\%; (II) 75\%; (III) 50\% and (IV) 25\% of the rain gauges of the basin. Additionally, a scenario considering the absence of monitoring was evaluated, in which the rainfall used in the modeling was estimated based on the TRMM satellite. Was verified that, in some situations, the modeling produced better results for scenarios with a lower rain gauges density if the available gauges presented better spatial distribution. Comparatively to the simulations performed with the rainfall estimated by the TRMM, the results obtained using rain gauges' data were better, even in scenarios with low rain gauges density. However, when the poor spatial distribution of the rain gauges was associated with low density, the satellite's estimation provided better results. Thus, was conclude that spatial distribution of the rain gauge network is important in the rainfall representation and that estimates obtained by the TRMM can be presented as alternatives for basins with a deficient monitoring network.
\end{abstract}

Keywords: Rainfall-runoff modeling; IPH II; Rain gauges scarcity; Product 3B42 version 7.

\section{RESUMO}

Nesse estudo foi avaliada a influência da densidade e distribuição da rede de monitoramento pluviométrico no resultado de simulações diárias chuva-vazão de um modelo concentrado (IPH II), considerando bacias hidrográficas com diferentes escalas de drenagem: Rio Turvo $\left(1.540 \mathrm{~km}^{2}\right)$, Rio Ijuí $\left(9.462 \mathrm{~km}^{2}\right)$, Rio Jacuí $\left(38.700 \mathrm{~km}^{2}\right)$ e Alto Uruguai $\left(61.900 \mathrm{~km}^{2}\right)$. Para isso, foram construídos quatro cenários de cobertura pluviométrica: (I) 100\% dos pluviômetros encontrados na bacia; (II) 75\% dos pluviômetros; (III) 50\% dos pluviômetros e; (IV) 25\% dos pluviômetros. Adicionalmente, foi avaliado um cenário considerando a ausência de monitoramento, em que a precipitação utilizada na modelagem foi estimada pelo satélite TRMM. Verificou-se que, em algumas situações, a modelagem produziu melhores resultados para cenários com menores densidades de pluviômetros, desde que estes apresentassem melhor distribuição espacial. Comparativamente às simulações realizadas com a chuva estimada pelo TRMM, os resultados obtidos por pluviômetros foram superiores, mesmo em cenários com baixa densidade. Entretanto, quando a má distribuição dos pluviômetros esteve aliada à baixa densidade, a estimativa do satélite forneceu resultados superiores. Deste modo, conclui-se que a distribuição espacial da rede pluviométrica é importante na representação da precipitação e que as estimativas obtidas pelo TRMM podem se apresentar como alternativas para bacias com rede de monitoramento deficitária.

Palavras-chave: Modelagem chuva-vazão; IPH II; Escassez de pluviômetros; Produto 3B42 versão 7. 


\section{INTRODUCTION}

Hydrological modeling is an important tool for water resources planning and management. It can be used for a variety of purposes, including the understanding of water dynamics, design of hydraulic structures, environmental management and analysis of climatic and human impacts on water resources, among others (FENG et al., 2018; LOPES et al., 2017; VIANA et al., 2018).

An adequate representation of the hydrological process requires, in addition to the appropriate model structure and parameters estimative, good quality data capable of accurately representing river basin hydrological functions (CABRAL; SAKURAG; SILVEIRA, 2017).

Although several data sources may introduce uncertainties in modeling results, precipitation is undoubtedly one of the main sources. Incorrect precipitation characterization could be associated with errors in flow and water level simulations, as it is one of the main inputs for hydrological models (JIMÉNEZ; COLLISCHONN, 2015; NIKOLOPOULOS; ANAGNOSTOU; BORGA, 2013; FENSTERSEIFER; ALLASIA; PAZ, 2016). Furthermore, the correct quantification of the precipitation is challenging due to its peculiar characteristics of occurrence, such as high spatial and temporal variability.

The conventional estimation of precipitation is performed by point measurements made by non-recording rain gauges (pluviometers) or recording rain gauges (pluviographs). Such instruments need to be in adequate quantity and distribution in the drainage area. This practice is a considerable challenge, especially for developing countries in South America due to the costs of monitoring networks' implementation and maintenance (SALIO et al., 2015).

In Brazil, for example, the insufficient and poor distribution of rain gauges, or even the large periods with faulty data in some basins is notorious, (FENSTERSEIFER; ALLASIA; PAZ, 2016). It occurs not only because of the high cost of maintaining these networks, but also by the difficulty of accessing some areas. Consequently, sometimes, the lack of information makes difficult or even prevents an adequate river basin management, as limits the number of available techniques and methods of analysis (ANDRADE, 2014; BUYTAERT et al., 2012). In this light, Candela et al. (2014) mentions that one of the most important research topics for water resources management is the developing of data acquisition strategies adaptable to ungagged basins.

This is especially important for convective events that are concentrated in small areas and characterized by high intensity and low duration. This kind of precipitation may occur at ungagged sites inside a basin and, therefore, not been recorded, but impacting runoff significantly (PEREIRA et al., 2013). This also occurs in mountainous regions due to orographic precipitation if the rain gauges are not adequately covering the area or placed in the opposite side of the mountains.

As an alternative to deficient quantification and inadequate distribution of rain gauges in the catchments, several remote sensing products were released that estimate rainfall by means of radars and meteorological satellites and other products (COLLISCHONN; COLLISCHONN; TUCCI, 2008; VIANA; FERREIRA; CONFORTE, 2010; LEIVAS et al., 2012; BAJRACHARYA et al., 2015; SALIO et al., 2015; FENSTERSEIFER; ALLASIA; PAZ, 2016; SOARES; PAZ; PICCILLI, 2016). Among the most used products in Brazil are the ones based on the European METEOSAT
(Meteorological Satellite) group, the North American GOES (Geostationary Operational Environmental Satellite) and the TRMM (Tropical Rainfall Measuring Mission).

TRMM satellite was designed to estimate precipitation in tropical and subtropical regions of the Earth, where two-thirds of the total precipitated on a global scale is concentrated (KUMMEROW et al., 2000). This satellite provided information from latitudes up to $50^{\circ} \mathrm{N}-\mathrm{S}$ and longitude $180^{\circ} \mathrm{W}-\mathrm{E}$ from January 1998 to mid-2015, totaling more than 17 years of data collection (NASA, 2017a). Although it is no longer in operation, the TRMM satellite data is still used and has major importance in the composition of historical series in ungagged regions.

Nevertheless, even alternative methods for rainfall estimative have strengths and weaknesses. For example, precipitation based on remote sensing, has an advantage in space coverage, but has limitations in terms of temporal sampling or spatial resolution. On the other hand, rain gauges network is efficient for direct measurement of punctual precipitation, but normally with a weak spatial coverage (CABRAL; SAKURAG; SILVEIRA, 2017; WU et al., 2017).

Thereby, several authors have analyzed the effect of precipitation uncertainties in hydrological modeling, by using both, rain gauges monitoring networks and estimates based on satellites and radars. Silans, Almeida and Porto (2009) evaluated the sensitivity of a distributed hydrological model to the spatial variability of the precipitation in the Gramame River Basin, with a drainage area of approximately $589 \mathrm{~km}^{2}$. These authors assessed the hydrological response of the model as they removed rain gauges from the available network, evaluating different densities and distribution. As the density decreased, the response of the model moved away from the reference simulation, as well as the sensitivity of the model changed according to the rain gauge's spatial distribution.

In the region of Veneto, northeastern Italy, Nikolopoulos et al. (2010) analyzed the effect of precipitation derived from 3B42 products, version 6 of the TRMM satellite and the one based on the algorithm described by Kidd et al. (2003) in the performance of a distributed hydrological model. The analysis was implemented at different basin scales, by dividing a basin into sub-basins between 100 and $1,200 \mathrm{~km}^{2}$ of area. Both precipitation estimates resulted in the similar model performances, however, for the smaller sub-basin, precipitation derived from 3B42 product did not perform well. This suggest that the performance of a satellite product is related not only to its resolution but also to basin scale.

Falck et al. (2015) analyzed the quality of precipitation estimates obtained by satellites in flow simulations in the Brazilian Tocantins-Araguaia River Basin (approximately 764,000 km²). They estimated precipitation from 4 satellite products (TRMM 3B42RT, CMORPH, Global Satellite Mapping of Precipitation - GSMaP and NOAA Hydroestimator - HYDRO-E) that were stochastically corrected and applied in 19 sub-basin scales, between 5,230 and $764,000 \mathrm{~km}^{2}$. The authors found out that the statistical measures RMSE and MAE (root mean square errors and mean absolute errors, respectively) indicated that the modeling errors tended to decrease as the drainage area of the basin increased.

In this way, it is investigated in this paper how the density and spatial distribution of the rainfall monitoring network affect the daily rainfall-runoff simulations of a lumped model by considering river basins with different drainage areas. It was also evaluated the quality of the precipitation obtained by the 
TRMM's product 3B42 version 7, against rain gauges data, for these river basins in different scales. Basins were selected considering topography conditions, land use and occupation, besides physiographic conditions, trying to analyze how rainfall monitoring network's density and spatial distribution affects flow prediction at different scales.

\section{MATERIAL AND METHODS}

Flow simulated by the IPH II rainfall-runoff model (BRAVO et al., 2006) for different scenarios varying rain gauge's density and spatial distribution and precipitation estimates of TRMM 3B42 satellite product was compared against observed flow in each basin. In the evaluation, efficiency indexes were used to measure the differences between the observed and simulated flow.

\section{Scales of analysis}

Four neighbors river basins with different drainage areas (between 1,540 $\mathrm{km}^{2}$ and 61,900 $\mathrm{km}^{2}$ ) were selected: Turvo River, Ijuí River, Jacuí River and Upper Uruguay. Except the Jacuí river basin, which belongs to the Guaíba hydrographic region, the others belong to the Uruguay River Basin (SEMA, 2012).

Turvo river basin was delimited at Três Passos gauging station (coded as ANA 74470000 by the Brazilian National Water Agency) with approximately $1,540 \mathrm{~km}^{2}$ of drainage area. Ijuí river basin was delimited at Ponte Mística gauging station (ANA 75320000), resulting in approximately $9,462 \mathrm{~km}^{2}$. Jacuí river basin comprises the sub-basins of the Upper Jacuí, Vacacaí, Vacacaí Mirim and part of the Lower Jacuí, and was delimited at Pardo River gauging station (ANA 85900000 ), totaling $38,700 \mathrm{~km}^{2}$. Upper Uruguay river basin has as main components the Pelotas, Canoas, Chapecó and Passo Fundo rivers and was delimited at Iraí gauging station (ANA 74100000), with approximately $61,900 \mathrm{~km}^{2}$.

The four selected river basins are completely or partially located in Rio Grande do Sul, the southernmost Brazilian state, between latitudes $26^{\circ}$ and $31^{\circ} \mathrm{S}$ and longitudes $49^{\circ}$ and $55^{\circ} \mathrm{W}$

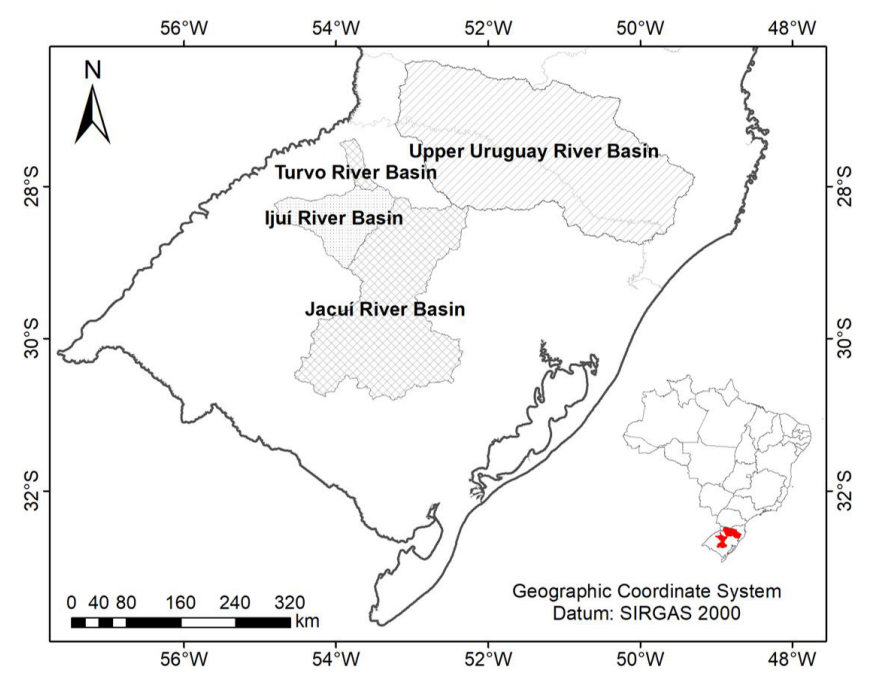

Figure 1. River basins location.
(Figure 1). Basins were chosen because they meet the requirements necessary to reach the objectives of this analysis (mainly data), and because they are located close enough to each other, avoiding possible differences in the response of the satellite sensor, due to the latitude.

\section{Data}

The input information required for calibration and validation of the IPH II hydrological model are precipitation, evapotranspiration and the observed flow at the time step of simulation - daily in this study. As IPH II is a lumped model, the input data were spatially grouped to represent average conditions for each river basin.

Consisted rain gauge's and flow data at daily time step were obtained from ANA's hydrological database HidroWeb (ANA, 2017) and from the Meteorological Database for Teaching and Research (BDMEP) of the Brazilian National Meteorological Institute (INMET, 2017) coinciding with TRMM derived data availability for the 1998-2014.

Precipitation estimates based on TRMM and auxiliary sources were obtained from 3B42 product, version 7 from NASA (2017b) for the period between January 1, 1998 and July 31, 2014, when TRMM was in operation. This data has temporal discretization of 3 hours, which represents eight images per day. The whole series used consists of 48,448 images and each pixel represent an area of $0.25 \times 0.25^{\circ}$.

Evapotranspiration data was estimated by water balance, using the precipitation and flow data measured from each river basin. The uncertainties generated by this methodology did not prove to introduce significative uncertainties in the development of this work, as indicated by a sequence of initial tests. These tests indicated that daily overestimations or underestimations of up to $50 \%$ in evapotranspiration did not result in significant differences in flow simulation using IPH II (PAULA, 2015).

During the different scenarios simulations, information of each river basin such as flow, initial conditions and the evapotranspiration were maintained unchanged. Thus, if eventual errors were committed in the estimative of evapotranspiration or in any other input information, it would be similar for all the flow simulations for that same basin and the result should be influenced solely by rainfall data.

\section{Rainfall scenarios}

To evaluate the influence of the density of the rainfall monitoring network and its spatial distribution on the simulated flow, were elaborated different rain gauge scenarios for each of the four river basins.

The first scenario was the real scenario (Real Scen) representing the density and distribution of the rain gauge network available in each river basin. In the sequence, were created three hypothetical scenarios in which were removed some rain gauges, generating conditions of scarcity and/or poor spatial rain gauges distribution in these areas. In a fifth scenario was considered the 
complete absence of rainfall monitoring, and the modeling was performed using the precipitation estimated based on 3B42 product.

For these scenarios, was used the following encodings: (I) Real Scen - 100\% of the existing rain gauges found in the basin; (II) $75 \%$ Scen - $75 \%$ of the total number of rain gauges and - (III) $50 \%$ Scen and (IV) $25 \%$ Scen - respectively; (V) TRMM Scen - 3B42 based data.
The selected rainfall monitoring stations to compose the hypothetical scenarios were randomly drawn. For each of the four basins were drawn the number of stations corresponding to each scenario (75\% Scen, 50\% Scen and 25\% Scen). This procedure resulted in 20 different precipitation time series (scenarios) that were used as input information in the IPH II model. Figure 2 shows the configuration of each of these scenarios.
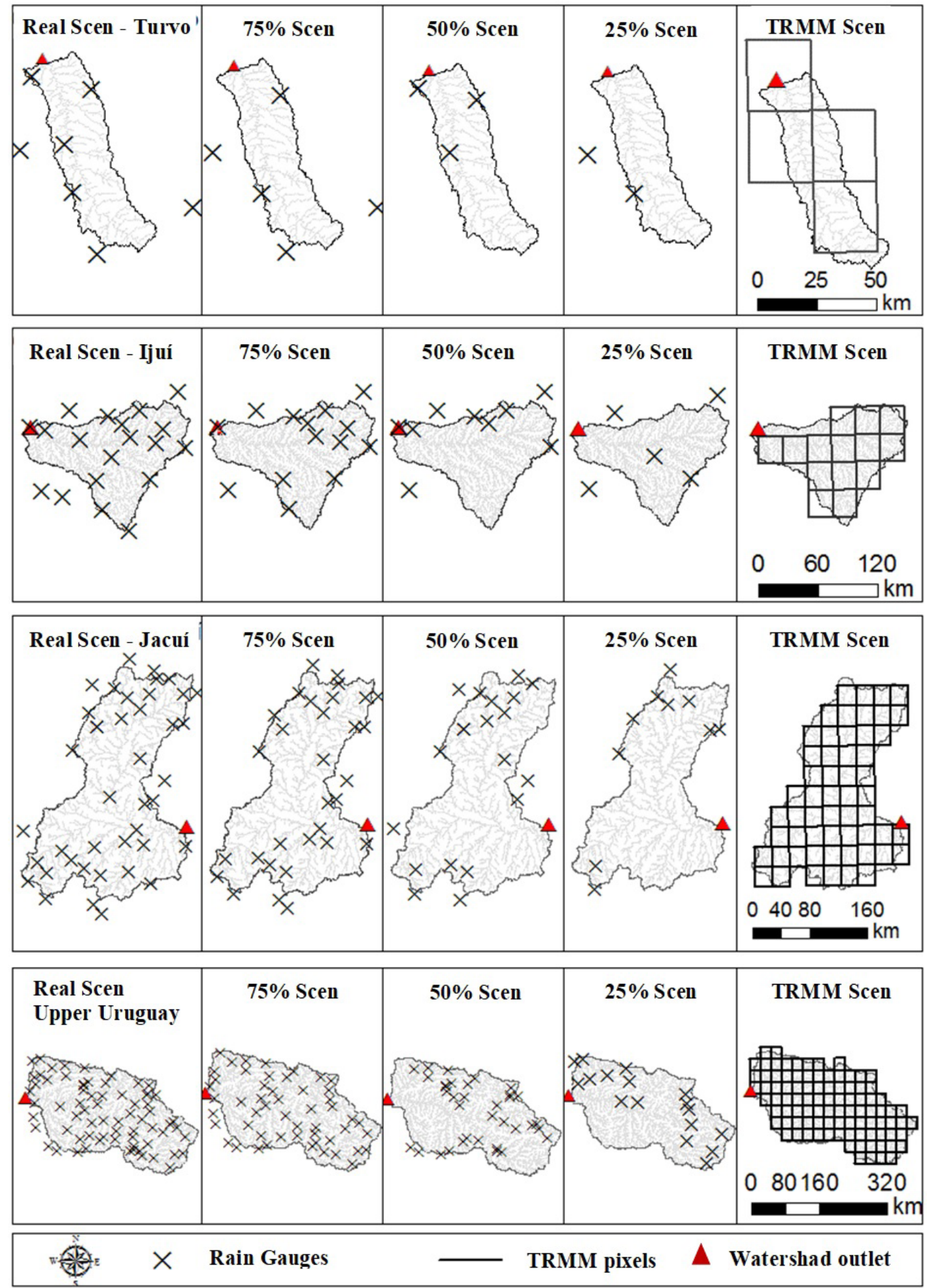

Figure 2. Rainfall monitoring scenarios on each river basin under analysis. 
Table 1. Quantity and density of rain gauges stations in each scenario.

\begin{tabular}{lcc}
\hline River basin/Scenario & $\begin{array}{c}\text { Number of } \\
\text { rain gauges } \\
\text { stations }\end{array}$ & $\begin{array}{c}\text { Monitoring } \\
\text { density } \\
\left.\mathbf{( k m}^{2} . \text { station }^{-1}\right)\end{array}$ \\
\hline Turvo & 7 & \\
Real Scen $(100 \%)$ & 5 & 220 \\
$75 \%$ Scen & 3 & 308 \\
$50 \%$ Scen & 2 & 513 \\
$25 \%$ Scen & & 770 \\
Ijuí & 19 & \\
Real Scen $(100 \%)$ & 14 & 497 \\
$75 \%$ Scen & 9 & 675 \\
$50 \%$ Scen & 5 & 1,050 \\
$25 \%$ Scen & & 1,890 \\
Jacuí & 41 & \\
Real Scen $(100 \%)$ & 31 & 944 \\
$75 \%$ Scen & 20 & 1,248 \\
$50 \%$ Scen & 10 & 1,935 \\
$25 \%$ Scen & & 3,870 \\
Upper Uruguay & 70 & 884 \\
Real Scen $(100 \%)$ & 52 & 1,190 \\
$75 \%$ Scen & 35 & 1,769 \\
$50 \%$ Scen & 17 & 3,641 \\
$25 \%$ Scen & & \\
\hline & &
\end{tabular}

Table 1 presents the number of rain gauges stations and rain gauge density in each scenario, in order to complement the information presented in Figure 2. It is possible to notice that in the case of TRMM, the spatial resolution is close to $25 \times 25 \mathrm{~km}$, which is equivalent to a density of approximately $625 \mathrm{~km}^{2}$.pixel- ${ }^{-1}$.

\section{Rainfall data}

Given the lumped nature of the IPH II model, first the observed rainfall values were spatialized for each scenario to later obtain the mean daily rainfall over the basin.

Rainfall from rain gauges was interpolated in regular grids with spatial resolution of $1 \mathrm{~km}$, by the Inverse Distance Squared Weighting (IDSW). IDSW was chosen due to the good results found in hydrological studies, according Marcuzzo, Andrade and Melo (2011). The arithmetic mean value of all pixels inside the basin area provided the average daily rainfall data for each basin. To automate the process, was used a GIS software with a sequence of script commands and routines made in FORTRAN. As products, were obtained four time series for each basin (Real Scen, $75 \%$ Scen, $50 \%$ Scen and $25 \%$ Scen) with a span of 6,056 days.

Except for the interpolation process, was applied the same procedure for determination of average daily rainfall for TRMM Scen. However, since the temporal discretization of the rainfall is 3 hours, differing from the daily information of the rain gauges, were added rainfall measured at eight 3-hours interval thus totalizing 24 hours.

In order to find the best interval integration, different starting and ending times were correlated with the Real Scen rainfall information, taken as reference due to the higher density of monitoring stations. The cumulative value from $12 \mathrm{~h}$ to $9 \mathrm{~h}$ UTC and advance of 1 day resulted in the highest correlation with the rain gauge data for all studied basins in agreement with results from Fensterseifer, Allasia and Paz (2016). Further information regarding this procedure can be found in Paula (2015) and Soares, Paz and Piccilli (2016).

The daily estimated rainfall of Real Scen in this procedure was then compared against the other four scenarios using visual analysis and obtaining the correlation coefficient (R) and the Volume Error (Errv). The correlation coefficient, Equation 1, indicates the degree of statistical relationship between two variables. This coefficient ranges from -1 to 1 , being 1 a perfect correlation or the strongest possible agreement and -1 the strongest possible disagreement.

$$
R=\frac{\sum_{i=l}^{n}\left(P_{\text {calci }}-\overline{P_{\text {calc }}}\right)\left(P_{100 \%}-\overline{P_{100 \%}}\right)}{\sqrt{\sum_{i=l}^{n}\left(P_{\text {calci }}-\overline{P_{\text {calc }}}\right)^{2} \sum_{i=l}^{n}\left(P_{100 \% i}-\overline{P_{100 \%}}\right)^{2}}}
$$

Where $P_{\text {calci }}$ is the value of the average rainfall $(\mathrm{mm})$ obtained from each scenario at time step $i ; P_{100 \% \mathrm{i}}$ is the average rainfall $(\mathrm{mm})$ from (Real Scen, $100 \%$ of rain gauges) at $I$; and $n$ is the number days in the period.

The total rainfall volume error (Equation 2) shows how similar are the average rainfall volume between each scenario and the one estimated in Real. As closer Errv to zero, the smaller is the error between both estimated volumes.

$$
\text { Errv }=100 \times \frac{\sum_{i=1}^{n}\left(P_{\text {calci } i}-P_{100 \%} i\right)}{\sum_{j=I}^{n} P_{100 \% i}}
$$

Where $P_{\text {calc } \mathrm{i}}$ is the average rainfall $(\mathrm{mm})$ for the scenario at time step I; $P_{100 \% \mathrm{i}}$ is the average rainfall $(\mathrm{mm})$ for Real Scen at $I$; and $n$ is the number days.

\section{Rainfall-runoff modeling with IPH II}

According to the data availability of each basin, were defined the periods used for calibration and validation (Real Scen, $75 \%$ Scen, 50\% Scen, 25\% Scen and TRMM Scen). Periods may vary between the different basins, but are the same between scenarios in the same basin.

During the calibration process (total of 20), was used mono-objective automatic calibration through genetic algorithms (see BRAVO et al., 2006 for details), and Nash-Sutcliffe efficiency (E) coefficient was used as objective function to assess the optimization process (Equation 3). The parameters defined for this process were 20 complexes with 40 individuals and 500 generations adopted because of computational limitations, due to the extension of the daily time series. After calibration, was evaluated the determination coefficient $\left(\mathrm{R}^{2}\right)$, according to Equation 4 , in addition to the efficiency coefficient available in the IPH II.

$$
\begin{aligned}
& E=1-\left[\frac{\sum_{i=I}^{n}\left(Q o_{i}-Q c_{i}\right)^{2}}{\sum_{i=I}^{n}\left(Q o_{i}-\overline{Q o}\right)^{2}}\right] \\
& R^{2}=\left\{\frac{\sum_{i=I}^{n}\left(Q o_{i}-\overline{Q o}\right)\left(Q_{c i}-\overline{Q c}\right)}{\left[\sum_{i=I}^{n}\left(Q o_{i}-\overline{Q o}\right)^{2}\right]^{0.5}\left[\sum_{i=I}^{n}\left(Q_{c i}-\overline{Q c}\right)^{2}\right]^{0.5}}\right\}^{2}
\end{aligned}
$$


Where $\mathrm{Q}_{\mathrm{oi}}$ is the observed flow $\left(\mathrm{m}^{3} \cdot \mathrm{s}^{-1}\right)$ at time step $\mathrm{i} ; n$ is the number of records; $\overline{Q o}$ is the average flow in the observed series $\left(\mathrm{m}^{3} \cdot \mathrm{s}^{-1}\right)$; and $\overline{Q c}$ is the average flow of the calculated series $\left(\mathrm{m}^{3} \cdot \mathrm{s}^{-1}\right)$.

The comparison between scenarios were accomplished by graphical analysis (including scatter plots) and, in quantitative terms, by the evaluation of $E$ and $R^{2}$ and other statistics such as mean value, standard deviation and values of maximum and minimum.

After the calibration, was performed the validation of results for each basin being all the scenarios evaluated separately.

\section{RESULTS AND DISCUSSION}

Influence of density and spatial distribution of rain gauges on rainfall estimation

The rainfall time series estimated for the scenarios with rain gauges data (\% Scen) and TRMM satellite information (TRMM Scen) were compared against the real rainfall time series (Real Scen), defined as reference. Figure 3 shows the estimates daily rainfall volumes

Turvo River Basin

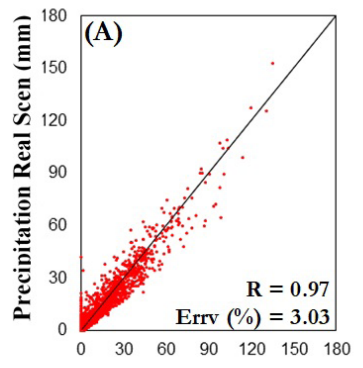

Pep 75\% Scen (mm)

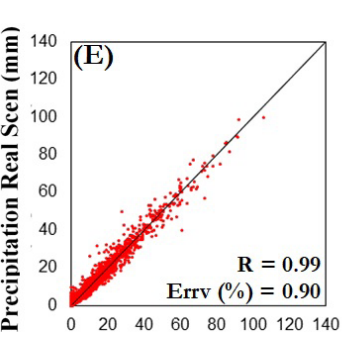

Pcp 75\% Scen (mm)

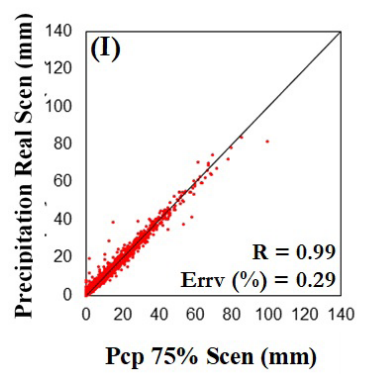

Pcp 75\% Scen (mm)

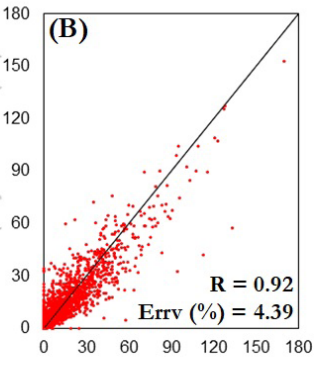

Pcp 50\% Scen (mm)

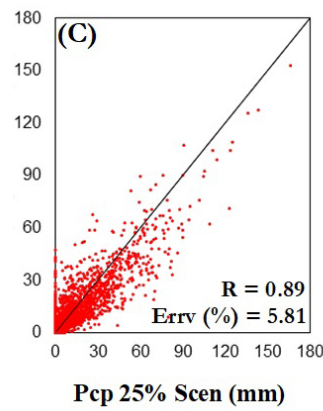

Ijuí River Basin

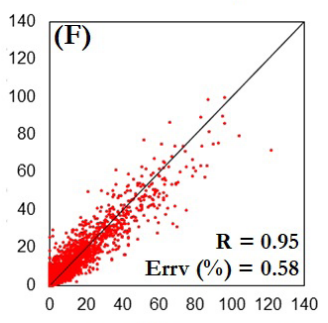

Pcp 50\% Scen (mm)

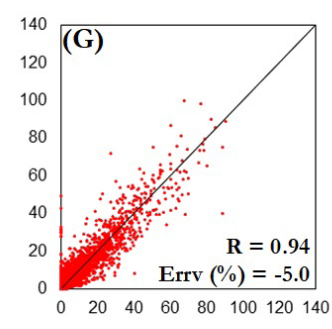

Pcp 25\% Scen (mm)
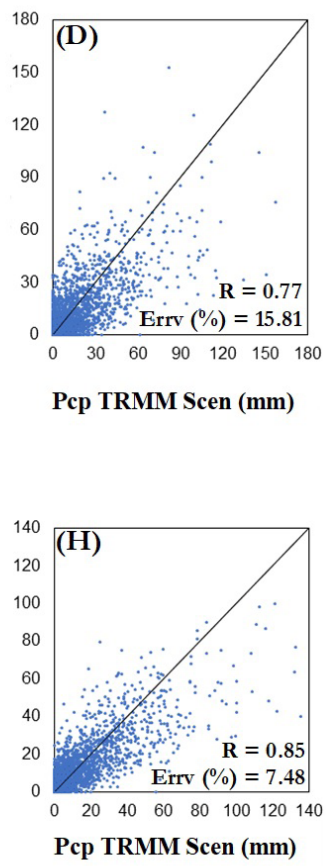

Jacuí River Basin

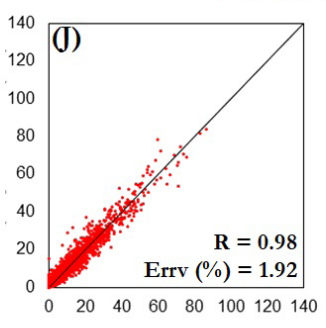

Pcp 50\% Scen (mm)
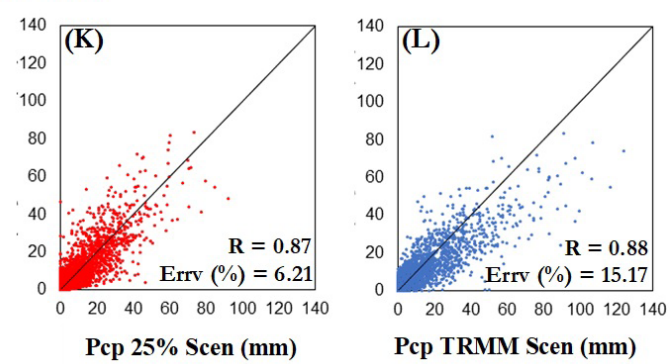

Upper Uruguay River Basin

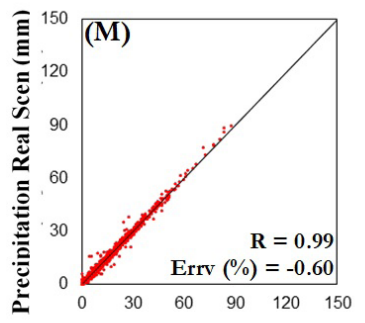

Pcp 75\% Scen (mm)

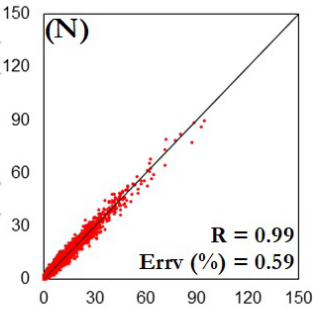

Pcp 50\% Scen (mm)

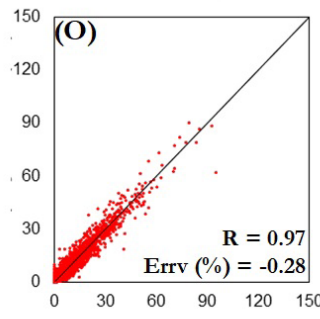

Pcp 25\% Scen (mm)

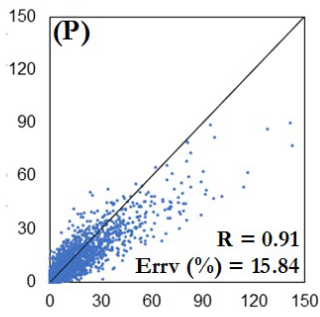

Pcp TRMM Scen (mm)

Figure 3. Dispersion between Real Scen precipitation time series (Pcp) against 75\% Scen, 50\% Scen, 25\% Scen and TRMM, for all basin spatial scales under analysis. 
and the dispersion between the series as well as their respective evaluation coefficients ( $R$ and Errv).

The analysis pointed out that the basin scale influenced in the quality of the average daily rainfall. When the drainage area increased, the rain gauges scarcity scenarios resulted, in most cases, in a smaller agreement between the estimated and the reference rainfall, even for TRMM rainfall. These results are evident when comparing the results between Turvo River Basin and the Upper Uruguay River Basin, the smallest and largest drainage area respectively, even if the larger basin has much lower rain gauge`s density.

When analyzed the density of rain gauges in the monitoring network $\left(\mathrm{km}^{2}\right.$.station $\left.{ }^{-1}\right)$, it was not possible to stablish a clear relationship between this factor and an improvement in results. For example, $25 \%$ Scen of the Turvo River Basin presented a density of one rain gauge every $770 \mathrm{~km}^{2}$ and a correlation with the Real Scen was $\mathrm{R}^{2}=0.89$; for the $25 \%$ Scen of the Upper Uruguay River Basin with a density of one rain gauge every $3,641 \mathrm{~km}^{2}, \mathrm{R}^{2}=0.97$. Therefore, although Upper Uruguay River Basin has lower density of rain gauges, when compared against Turvo River Basin, its $\mathrm{R}^{2}$ remained noticeably higher (in relation to the Real Scen).

In this sense, results indicate that information about the number of rain gauges and/or density must be allied to their distribution conditions and the basin area. In this study, the precipitation estimates for smaller river basin were most sensitive to the lack of rain gauges than the larger ones.

The rain gauges spatial distribution also performed as an important factor in the average rainfall values. For example, when analyzing the rain gauges' distribution of the $50 \%$ Scen of the Ijuí River Basin, it did not cover the basin as well as then $25 \%$ Scen network. Consequently, although the number of rain gauges was halved $\mathrm{R}^{2}$ was practically the same, decreasing minimally, from 0.95 to 0.94 .

The TRMM scenarios presented a similar behavior to the rain gauge's scenarios, with lower dispersion for larger watersheds, as can be seen in Figures 3D, 3H, 3L and 3P. However, except for Jacuí River Basin, the average rainfall estimated by TRMM did not provide better results than the estimate with rain gauges, even in low density scenario.
In the Jacuí River Basin, TRMM scenario produced better results when compared to $25 \%$ Scen (Figure $3 \mathrm{~K}$ and $3 \mathrm{~L}$ ), with $\mathrm{R}$ increasing from 0.87 to 0.88 . Although small, this increase in the correlation indicates a higher reliability of the rainfall estimates by TRMM satellite data, when there is a condition of low density of rain gauges coupled with a poor spatial distribution, such as observed in the $25 \%$ Scen of this river basin.

Overall, the volume error were small for the hypothetical scenarios (\% Scen). The lowest values were found at the Upper Uruguay River Basin and the largest ones for the Turvo River Basin. It is noteworthy that in most cases there was a rainfall overestimation, when compared with the real scenario. The TRMM satellite overestimated rainfall by approximately $15 \%$ in all river basins, except for the Ijuí River Basin, in which it was approximately 7.5\% in agreement with results presented by Fensterseifer, Allasia and Paz (2016) and Schiavo Bernardi et al. (2015) in the same region.

In summary, the low rain gauge's density compromised the estimative of average daily rainfall, especially for smaller river basins. TRMM's estimates proved not to be enough to replace rain gauges' data, except in a condition of large rain gauges' scarcity coupled with poor spatial distribution. Even in these cases, the satellite data needs corrections to improve accuracy.

\section{Rainfall-runoff in the different river basins scales}

\section{Turvo River Basin (1,540 $\left.\mathrm{km}^{2}\right)$}

Was considered the period from March 22, 1999 to May 31, 2005 to calibrate the IPH II's parameters of the Turvo River Basin. The model's validation used the period from January 1, 2012 to July 29, 2014.

Table 2 shows that the mean and minimum values of simulated flow for this watershed remained close to the observed in the different evaluated scenarios. The maximum simulated flows values were underestimated compared to the maximum observed value, which expresses the difficulty of IPH II to represent the

Table 2. Statistics for the different scenarios for all the basins.

\begin{tabular}{|c|c|c|c|c|c|c|c|}
\hline \multirow[b]{2}{*}{ River Basin } & \multirow[b]{2}{*}{ Parameter } & \multicolumn{6}{|c|}{ Flows of precipitation scenarios $\left(\mathrm{m}^{3} / \mathrm{s}\right)$} \\
\hline & & Observed Flow & Real Scen & $75 \%$ Scen & $50 \%$ Scen & $25 \%$ Scen & $\begin{array}{c}\text { TRMM } \\
\text { Scen }\end{array}$ \\
\hline \multirow[t]{4}{*}{ Turvo River } & Mean & 39 & 40 & 42 & 40 & 43 & 42 \\
\hline & Maximum & 522 & 490 & 343 & 312 & 319 & 302 \\
\hline & Minimum & 4 & 2 & 2 & 4 & 5 & 4 \\
\hline & Standard deviation & 39 & 29 & 32 & 33 & 31 & 31 \\
\hline \multirow[t]{4}{*}{ Ijui River } & Mean & 236 & 233 & 233 & 238 & 243 & 237 \\
\hline & Maximum & 1,427 & 1,436 & 1,444 & 1,635 & 1,687 & 1,368 \\
\hline & Minimum & 43 & 9 & 30 & 9 & 16 & 15 \\
\hline & Standard deviation & 205 & 207 & 210 & 170 & 203 & 164 \\
\hline \multirow[t]{4}{*}{ Jacuí River } & Mean & 724 & 723 & 721 & 714 & 737 & 806 \\
\hline & Maximum & 4,482 & 5,409 & 5,563 & 5,213 & 4,590 & 4,454 \\
\hline & Minimum & 83 & 41 & 27 & 26 & 27 & 58 \\
\hline & Standard deviation & 698 & 642 & 661 & 661 & 666 & 626 \\
\hline \multirow[t]{4}{*}{ Upper Uruguay River } & Mean & 1,700 & 1,776 & 1,776 & 1,770 & 1,704 & 1,688 \\
\hline & Maximum & 15,266 & 15,759 & 15,663 & 16,088 & 15,609 & 9,567 \\
\hline & Minimum & 293 & 101 & 103 & 93 & 85 & 243 \\
\hline & Standard deviation & 1,602 & 1,414 & 1,418 & 1,400 & 1,425 & 1,245 \\
\hline
\end{tabular}


peak flow. Table 3 presents the evaluation coefficients $\mathrm{E}$ and $\mathrm{R}^{2}$, resulting from calibration and validation. In Figure 4 are presented only the scatter plots between the observed and calculated flow obtained in the calibration step, since those achieved in validation step were similar.
During calibration, $75 \%$ Scen resulted in superior results (E 0.62 and $\mathrm{R}^{2}$ 0.63) than those generated for the Real Scen ( $\mathrm{E}$ and $\mathrm{R}^{2}$ both with a 0.59 value), and for other hypothetical scenarios. In Figure 4 can be observed that the simulated flow for the $75 \%$ Scen presented less dispersion in relation to the other

Table 3. Results of the evaluation coefficients for Turvo River Basin.

\begin{tabular}{ccccccc}
\hline \multirow{2}{*}{ Modeling step } & Evaluation & \multicolumn{5}{c}{ Rainfall Scenarios } \\
\cline { 2 - 7 } & coefficients & Real Scen & $\mathbf{7 5 \%}$ Scen & $\mathbf{5 0 \%}$ Scen & 25\% Scen & TRMM Scen \\
\hline Calibration & $R^{2}$ & 0.59 & 0.63 & 0.57 & 0.55 & 0.47 \\
\multirow{3}{*}{ Validation } & $E$ & 0.59 & 0.62 & 0.55 & 0.53 & 0.44 \\
& $R^{2}$ & 0.69 & 0.67 & 0.61 & 0.61 & 0.51 \\
\hline
\end{tabular}
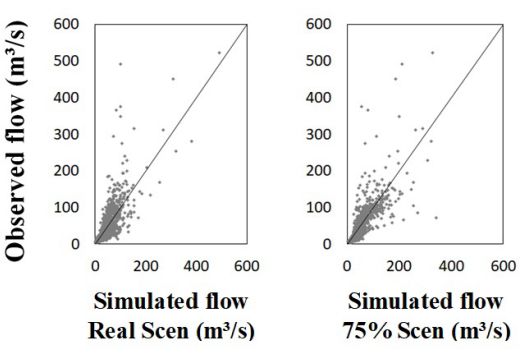

Turvo River Basin
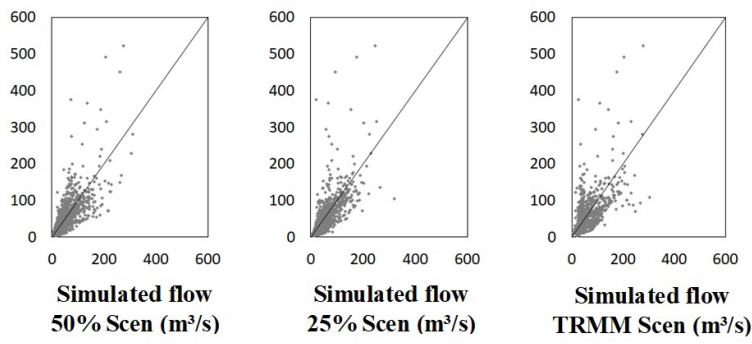

Ijuí River Basin
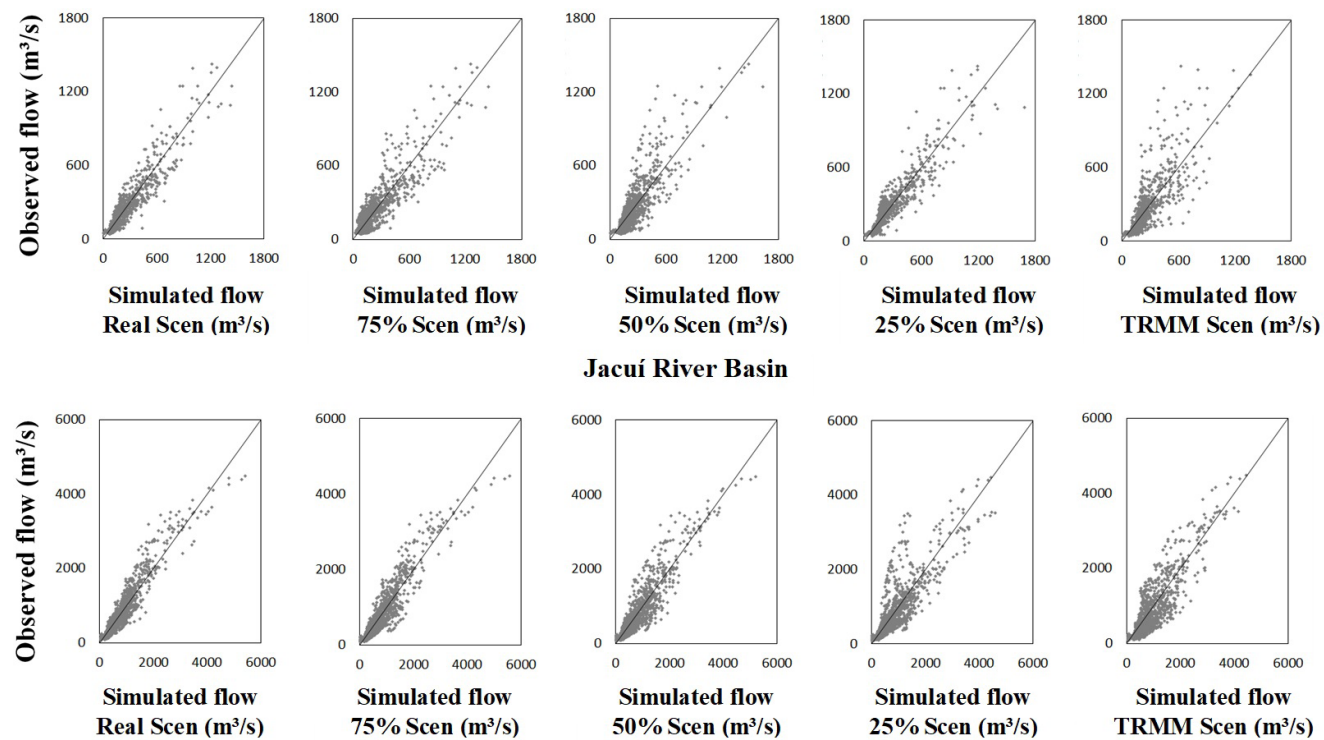

Jacuí River Basin
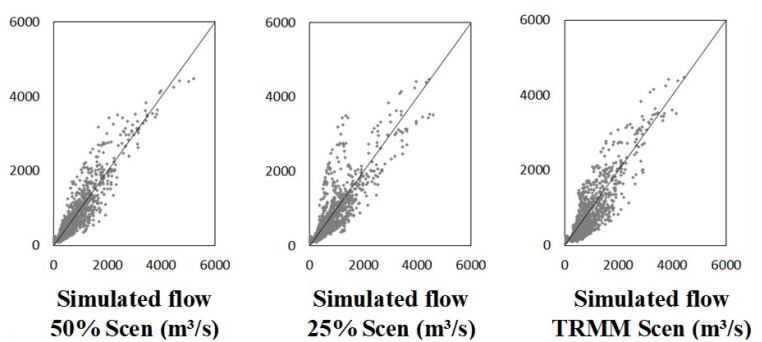

Upper Uruguay River Basin
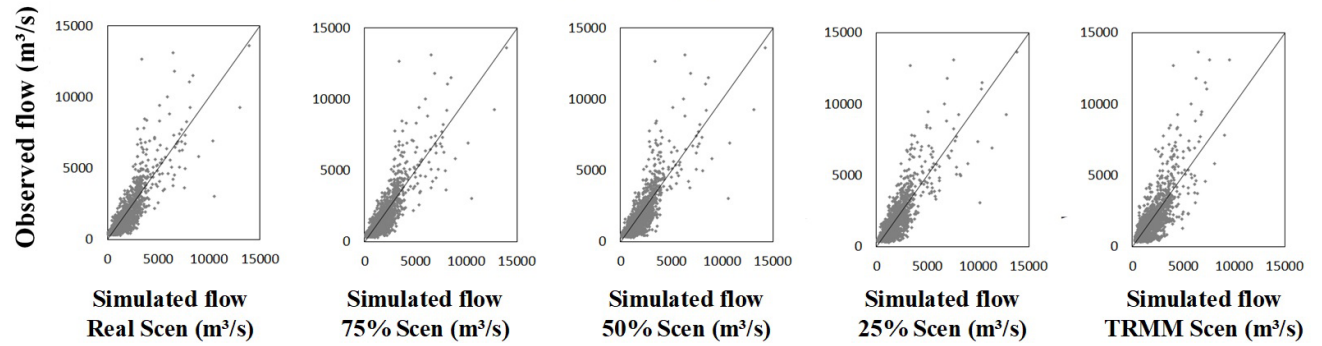

Figure 4. Dispersion between observed flow against simulated flow for scenarios: Real Scen, 75\% Scen, 50\% Scen, 25\% Scen and TRMM, for all basins. 
ones. A similar behavior in validation step was observed for the coefficient E. In Figure 5 we can see graphically the adequacy between the observed and simulated flow in the calibration step for $75 \%$ Scen. This could be related with problems in the rain registry (because of problems with the equipment, observer, or position of the rain gauge, Tucci, 2013).

Galdino, Bravo and Gutierrez (2014) found similar results when they evaluated the influence of the number of rain gauges used in the estimation of the average rainfall series used as input for the adjustment of IPH II. The authors identified that, as they disregarded some rain gauges in the calculation of average rainfall, the model showed an improvement in flow simulation performance. This behavior is due mainly to the characteristic of high spatial variability of the precipitation in the basin, which need to be represented by a single average precipitation in the lumped model. It is also affected by errors related to the rain gauges measurements and placement.

Therefore, for the Turvo River Basin, the five rain gauges (75\% Scen) produced a better result for the simulated flow when compared to the seven rain gauges (Real Scen). Should be noted that the rain gauges Três Passos (ANA 2753009) and Campo Novo (ANA 2753025) were the ones that impacted negatively the simulated flow. However, it should be considered that all precipitation scenarios evaluated for this river basin produced $\mathrm{E}$ and $\mathrm{R}^{2}$ coefficients higher than 0.5 , which is considered satisfactory by several authors (SANTHI et al., 2001; VAN LIEW; ARNOLD; GARBRECHT, 2003; COLLISCHONN, 2006; KOUCHI et al., 2017).

The simulated flows using TRMM satellite data produced the lower quality results ( $\mathrm{E}$ equal 0.44 in the calibration and validation and $R^{2}$ equal 0.47 and 0.51 in the calibration and validation, respectively). Somehow was expected this result because of the relatively small area of the Turvo River Basin (approximately 1,540 $\mathrm{km}^{2}$ ) compared to satellite pixels area (4 pixels of approximately $625 \mathrm{~km}^{2}$, totaling 2,500 $\mathrm{km}^{2}$ ). In other words, the average rainfall estimated by the satellite data covered an area much higher than the real area of the basin, which resulted in greater uncertainties regarding the rain gauges data.

\section{Ijui River Basin (9,462 km²)}

In the Ijuí River Basin was considered the period from February 24, 1999 to March 31, 2002 for calibration and from January 10, 2006 to September 21, 2007, for validation. Table 4 presents the evaluation coefficients $E$ and $R^{2}$ and some basic statistical parameters are presented in Table 2. In this basin, can be observed that the maximum flow for $50 \%$ Scen and $25 \%$ Scen were overestimated, while minimum values were underestimated in all evaluated scenarios (Table 2). The simulated mean flow remained close to observed in all scenarios. Figure 4 shows the scatter plots between observed and simulated flows.

The best performance was obtained with precipitation of Real Scen (Figures 4 and 6) with decreasing efficiency as the density of rain gauges was reduced accordingly in the $75 \%$ Scen and $50 \%$ Scen. For 25\% Scen, the result was equivalent to the Real Scen in calibration, although it represents a condition in which the rainfall is estimated with only one-fourth of the rain gauges. This good result was associated to the adequate distribution of rain gauges in $25 \%$ Scen, where they were better spatially distributed when compared to $50 \%$ and $75 \%$ scenarios being the model able to capture the spatial variability of the precipitation.

Among the evaluated rainfall scenarios, the simulated flow with the TRMM data were the ones that presented the worst results. In the validation stage, the value of $E$ reached -0.57 , which can be justified by the difference in humidity between the calibration (wetter) and validation (drier) periods. Should be noted that the selected calibration and validation periods were chosen because of the continuous time series without faulty data, which made difficult with homogeneous humidity. In this way, can be explained the significant loss of efficiency (E) in the validation period for all scenarios in this Basin.

Table 4. Results of the evaluation coefficients for the Ijuí River Basin.

\begin{tabular}{ccccccc}
\hline \multirow{2}{*}{ Modeling step } & \multirow{2}{*}{$\begin{array}{c}\text { Evaluation } \\
\text { coefficient }\end{array}$} & Real Scen & $\mathbf{7 5 \% \text { Scen }}$ & $\mathbf{5 0 \% \text { Scen }}$ & $\mathbf{2 5 \% \text { Scen }}$ & TRMM Scen \\
\cline { 3 - 7 } & $\mathrm{R}^{2}$ & 0.87 & 0.79 & 0.74 & 0.86 & 0.67 \\
Calibration & $E$ & 0.87 & 0.77 & 0.74 & 0.86 & 0.67 \\
Validation & $\mathrm{R}^{2}$ & 0.79 & 0.76 & 0.74 & 0.71 & 0.56 \\
& $E$ & 0.63 & 0.68 & 0.47 & 0.59 & -0.57 \\
\hline
\end{tabular}

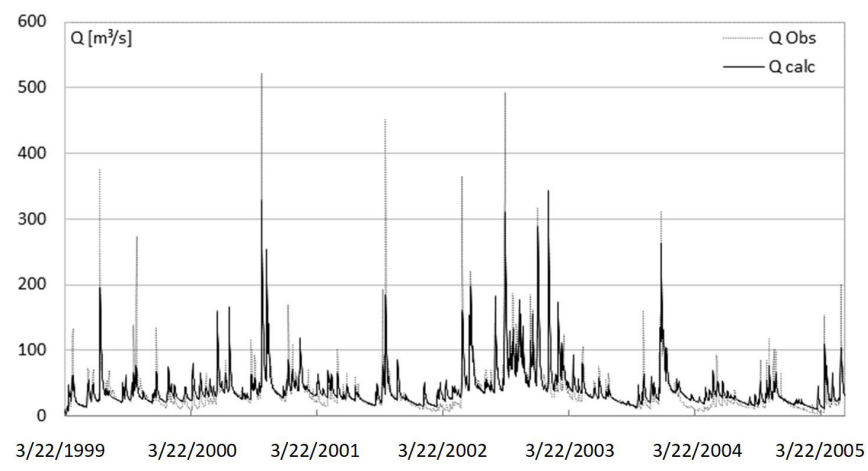

Figure 5. Observed and simulated daily flows for the 75\% Scen of the Turvo River Basin, for the calibration step.

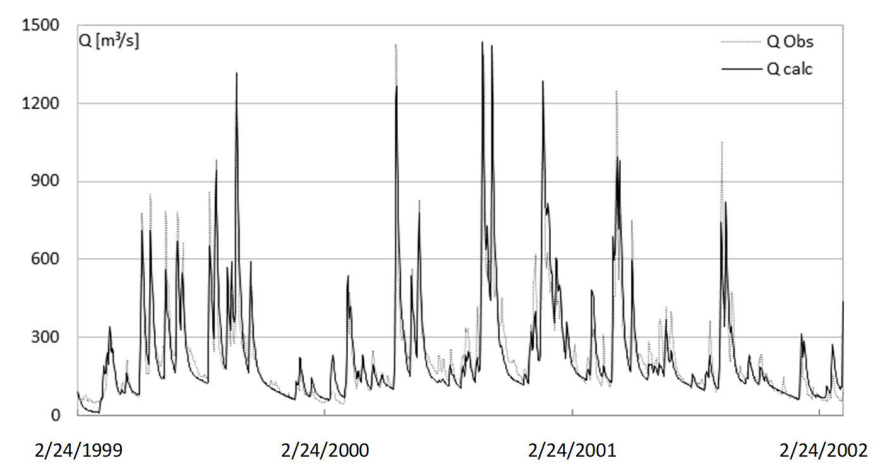

Figure 6. Observed and simulated daily flows for the Real Scen of the Ijuí River Basin, for the calibration step. 


\section{Jacui River Basin (38,700 k $\left.\mathrm{km}^{2}\right)$}

In the Jacuí River Basin was considered the period from January 2, 2005, to December 31, 2008, and from July 24, 2012, to July 29, 2014, to calibrate and validate the model, respectively (Tables 2 and 5). In this basin, the maximum flow was, in general, overestimated - except the value of TRMM Scen and the minimum underestimated, so the standard deviation presented close values between the different scenarios. In relation to the mean values, the one obtained by the TRMM Scen was overestimated and those obtained for the other scenarios were close to the average value of observed flow rate, confirming the bias towards higher rainfall values of $3 \mathrm{~B} 42$.

The Real Scen obtained the best performance of the model (Figures 4 and 7), with loss of efficiency as the model reduced the number of rain gauges to estimate the mean precipitation.

Despite the decrease in $\mathrm{E}$ and $\mathrm{R}^{2}$ in all scenarios from the Real Scen, it is worth noting the sharp reduction at 25\% Scen. Even though it remained above the limit considered satisfactory in the calibration (greater than 0.5 ), it presented poor validation performance, resulting in an $\mathrm{E}$ of 0.39 . Possibly this result is associated to the poor distribution of the rainfall stations used in the estimation of the spatial mean rainfall in this scenario as the stations are located only in the upstream region of this large basin.

TRMM Scen produced better results when compared to those generated by $25 \%$ Scen, both in calibration and validation. This result confirms the importance of the good spatial distribution of rain gauges for the estimation of the spatialized average rainfall. It indicates that, under conditions of high scarcity and poor distribution of rain gauges, the use of satellite estimates in a lumped rainfall-runoff modeling may present higher results.

\section{Upper Uruguay River Basin (61,900 k.m²)}

Was considered the period from June 5, 2000, to February 28,2005 , for calibration, with a mean flow rate of $1,700 \mathrm{~m}^{3} \cdot \mathrm{s}^{-1}$. The validation occurred in the period between August 27, 2005, and September 8, 2009, with a mean flow rate of 1,485 $\mathrm{m}^{3} \cdot \mathrm{s}^{-1}$. $E$ and $R^{2}$ are presented in Table 6 and statistics in Table 2. Maximum flow obtained from 3B42 for TRMM Scen was underestimated when compared to the other scenarios. Minimum flows were underestimated compared to the minimum observed value for all scenarios. This has repercussions on the results found for the standard deviations, which resulted lower than for the observed flow. Average flows remained close between the different scenarios (Table 2 and Figure 4).

Compared against Ijuí and Jacuí basins, the result obtained in this basin were worse. There is a greater dispersion between the observed and calculated flow for all the scenarios (Figure 4). This was expected due to the area of the Upper Uruguay River Basin that is beyond the scope of IPH II model, even if this basin presented the best results in the rainfall analysis for all scenarios. Also, previous studies have indicated a high heterogeneity in the physical characteristics of this basin, which influences the performance of lumped models.

In addition to the high spatial heterogeneity, in the Upper Uruguay River basin should also be considered the changes in the hydrological regime induced by hydroelectric power stations not represented specifically in the lumped model. Among the main hydroelectric plants included in this basin, may be mentioned: Campos Novos in the Canoas River; Barra Grande and Machadinho in the Pelotas River; Itá, which is the largest hydroelectric dam in Rio Grande do Sul State and Foz do Chapecó in the Uruguay

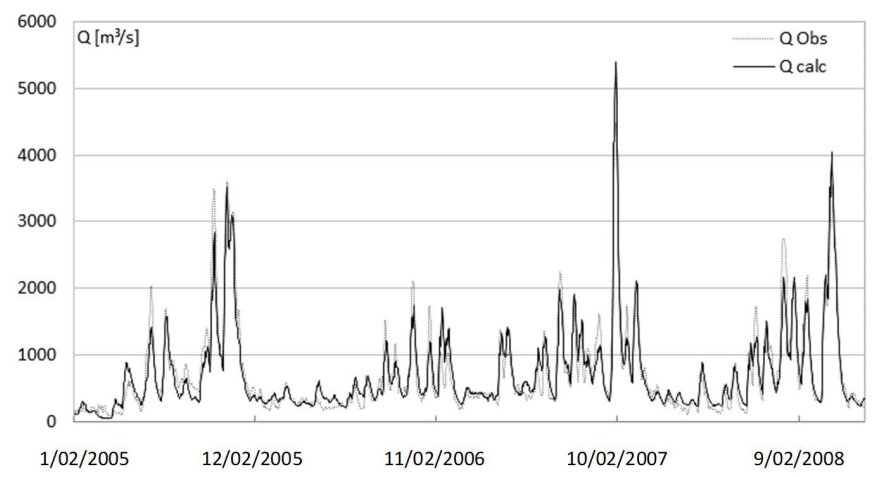

Figure 7. Observed and simulated daily flows for the Real Scen of the Jacuí River Basin, for the calibration step.

Table 5. Results of the evaluation coefficients for the Jacuí River Basin.

\begin{tabular}{ccccccc}
\hline \multirow{2}{*}{ Modeling step } & \multirow{2}{*}{$\begin{array}{c}\text { Evaluation } \\
\text { coefficient }\end{array}$} & Real Scen & $\mathbf{7 5 \% \text { Scen }}$ & $\mathbf{5 0 \%}$ Scen & 25\% Scen & TRMM Scen \\
\cline { 3 - 7 } Calibration & $\mathrm{R}^{2}$ & 0.90 & 0.88 & 0.86 & 0.74 & 0.78 \\
& $E$ & 0.90 & 0.88 & 0.86 & 0.73 & 0.77 \\
Validation & $\mathrm{R}^{2}$ & 0.67 & 0.66 & 0.62 & 0.47 & 0.62 \\
& $E$ & 0.66 & 0.64 & 0.58 & 0.39 & 0.57 \\
\hline
\end{tabular}

Table 6. Results of the evaluation coefficients for the Upper Uruguay River Basin.

\begin{tabular}{ccccccc}
\hline \multirow{2}{*}{ Modeling step } & \multirow{2}{*}{ Evaluation coeficiente } & \multicolumn{5}{c}{ Rainfall Scenarios } \\
\cline { 3 - 7 } & & Real Scen & $\mathbf{7 5 \%}$ Scen & $\mathbf{5 0 \% \text { Scen }}$ & $\mathbf{2 5 \%}$ Scen & TRMM Scen \\
\hline Calibration & $\mathrm{R}^{2}$ & 0.71 & 0.71 & 0.69 & 0.70 & 0.61 \\
\multirow{2}{*}{ Validation } & $E$ & 0.71 & 0.71 & 0.69 & 0.70 & 0.61 \\
& $\mathrm{R}^{2}$ & 0.57 & 0.56 & 0.52 & 0.57 & 0.38 \\
\hline
\end{tabular}




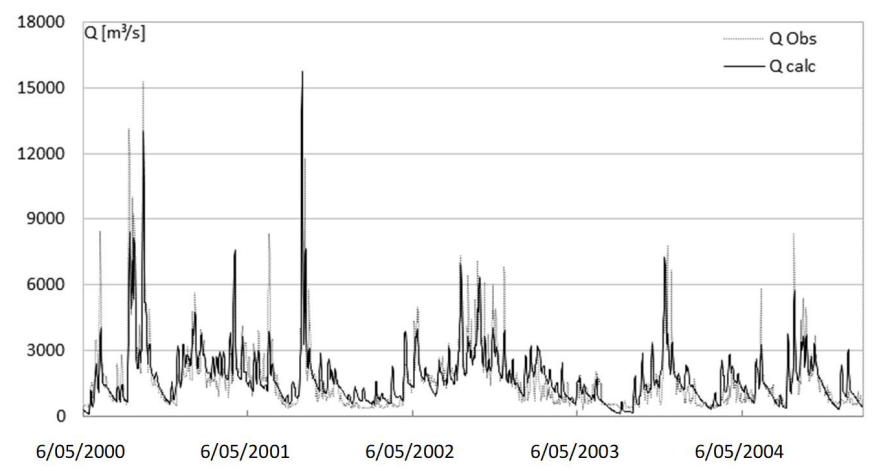

Figure 8. Observed and simulated daily flows for the Real Cen of the Upper Uruguay River Basin, for the calibration step.

River as well as several small hydroelectric power plants in the tributaries. It is important to note, that due to the widespread use of hydroelectricity, it is not possible to find in the region basins that met the criteria established in the methodology (area, distribution of rain and stream gauges and climatological stations).

However, even with these limitations, the results should be considered at least acceptable, with the exception of the TRMM Scen. Figure 8 shows that Real Scen produced slightly better results than the other scenarios.

In this light, if better results are required, it is recommended the use of a distributed hydrological model, suitable for the scale of the basin and capable of representing dams.

\section{General comments}

Results clearly showed that the basin scale influenced the quality of the results as the area increased from $1,540 \mathrm{~km}^{2}$ to $61,900 \mathrm{~km}^{2}$. When the drainage area increased, the rain gauges scarcity scenarios resulted, in most cases, in a smaller difference between the estimated and the reference rainfall, even for TRMM rainfall, demonstrating the more susceptibility to uncertainties in rainfall characterization in the smaller basins.

However, when analyzed the density of rain gauges in the monitoring network $\left(\mathrm{km}^{2} \cdot\right.$ station $\left.^{-1}\right)$, it was not possible to establish a clear relationship between this factor and an improvement in results, representing that information about the rain gauges density must be linked to their distribution.

During rainfall-runoff simulation, there was not a pattern in the flows' overestimation or underestimation between the different scenarios evaluated, as is shown in Figure 4. The efficiency in flow generation improved as the basin area increased, until reaching a certain scale when results lost quality. This should be related to the performance limitations of lumped models and specifically to IPH II scope.

Similar behavior was also observed when using rainfall from TRMM satellite data. In this case, the quality of the simulated flow changes from not acceptable ( $\mathrm{E}$ and $\mathrm{R}^{2}$ less than 0.5$)$ to acceptable ( $E$ and $R^{2}$ between 0.5 and 0.75 ) and very good (greater than 0.75 ), as the drainage area increased from $1,540 \mathrm{~km}^{2}$ to $9,462 \mathrm{~km}^{2}$, and then to $38,700 \mathrm{~km}^{2}$.

In the largest basin, the Upper Uruguay River Basin, with $61,900 \mathrm{~km}^{2}$, results were not so good due to the limitations of the
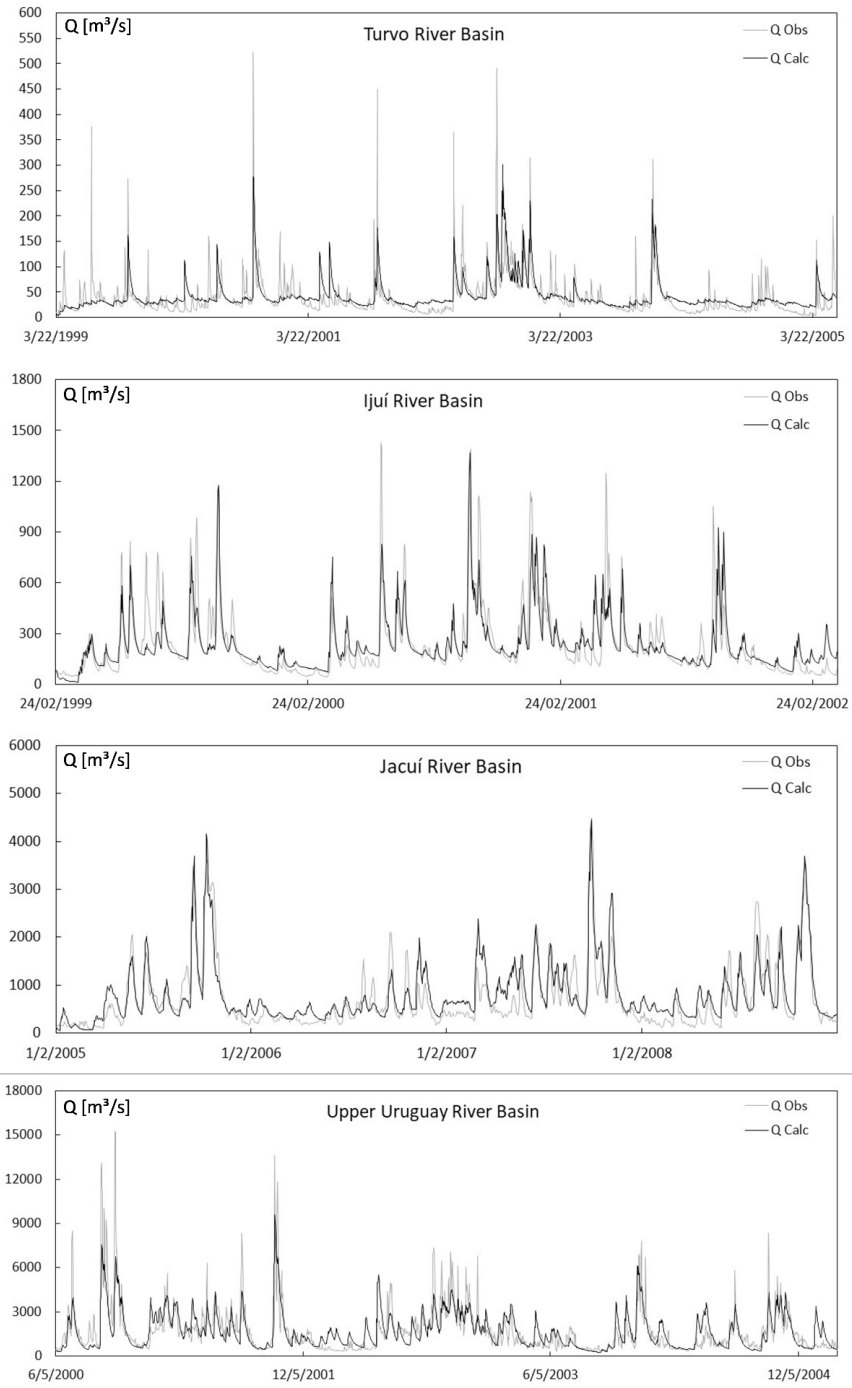

Figure 9. Observed and simulated daily flows for calibration step, in the four basins scales, for the TRMM Scenario.

model already discussed. However, despite the reduction in the $\mathrm{E}$ and $\mathrm{R}^{2}$ coefficients, when compared with the immediately smaller area basin (the Jacuí River Basin), these remained in ranges considered acceptable for the calibration step. This could be also observed in the result of TRMM scenario across de different basins (Figure 9).

\section{CONCLUSION}

In this work, was analyzed how the density and spatial distribution of the rainfall monitoring network can influence the performance of the IPH II, a lumped hydrological model, considering river basins with different areas. In a complementary way, was also evaluated the possibility of TRMM 3B42 product, version 7 , in substitution of rain gauges data, in order to represent an ungagged basin situation in different scales.

Was found that the number of rain gauge stations is important for the accuracy of the estimative of average daily rainfall used as input data in the lumped model. However, the basin drainage area and the rain gauge spatial distribution were 
more relevant for this estimation than the number of stations in the area (i.e. density).

Furthermore, scenarios, where rain gauges were spatially well-distributed in the basin, produced better model performances during rainfall-runoff simulations, compared to those with poor distribution, even when rain gauges were in larger numbers in accordance with results presented by Silans, Almeida and Porto (2009). Results also showed that smaller river basins are more sensitive to low rain gauges density during flow simulation than the larger ones. In this way, information related to rain gauges' spatial distribution and density should be taken into account in the modeling process. Additionally, simulated flows by using rain gauges data produced better model performance than using TRMM rainfall estimates, even for low rain gauge density scenarios. However, when low rain gauges density was associated with poor spatial distribution, the TRMM satellite data appeared as a viable alternative.

In this sense, the rainfall estimation by means of TRMM, one of the most widespread and used satellites to estimate tropical precipitation, may be a feasible alternative, particularly for large ungagged river basins.

\section{ACKNOWLEDGEMENTS}

For their support to the National Council for Scientific and Technological Development (CNPq) and the National Council for the Improvement of Higher Education (CAPES).

\section{REFERENCES}

ANA - AGÊENCIA NACIONAL DE ÁGUAS. Sistema de informações hidrológicas. 2017. Available from: < http:// hidroweb. ana.gov.br/>. Access on: 15 feb. 2017.

ANDRADE, L. F. Análise espaço-temporal do escoamento fuvial nas bacias hidrográficas dos rios Aguapeí e Peixe, Oeste Paulista, Brasil. 2014. 138 f. Dissertação (Mestrado em Geografia) - Universidade Estadual Paulista, Presidente Prudente, 2014.

BAJRACHARYA, S. R.; PALASH, W.; SHRESTHA, M. S.; KHADGI, V. R.; DUO, C.; DAS, P. J.; DORJI, C. Systematic evaluation of satellite-based rainfall products over the brahmaputra basin for hydrological applications. Advances in Meteorology, v. 2015, p. 17, 2015. http://dx.doi.org/10.1155/2015/398687.

BRAVO, M. J.; ALLASIA, D. G.; COLLISCHONN, W.; TASSI, R.; MELLER, A.; TUCCI, C. E. M. WIN_IPH2: Modelo IPH2 para Windows®. Manual de Conceitos Versão 1.0. Porto Alegre: UFRGS/IPH, 2006.

BUYTAERT, W.; FRIESEN, J.; LIEBE, J.; LUDWIG, R. Assessment and management of water resources in developing, semi-arid and arid regions. Water Resources Management, v. 26, n. 4, p. 841-844, 2012. http://dx.doi.org/10.1007/s11269-012-9994-3.

CABRAL, S. L.; SAKURAG, J.; SILVEIRA, C. S. Incertezas e erros na estimativa de vazões usando modelagem hidrológica e precipitação por RADAR. Revista Ambiente \& Água, v. 12, n. 1, p. 57-70, 2017. http://dx.doi.org/10.4136/ambi-agua.1924.

CANDELA, L.; ELORZA, F. J.; TAMOH, K.; JIMÉNEZ, MARTÍNEZ, J.; AURELI, A. Groundwater modeling with limited data sets: the Chari-Logone area (Lake Chad Basin, Chad). Hydrological Processes, v. 28, n. 11, p. 3714-3727, 2014. http://dx.doi.org/10.1002/hyp.9901.

COLLISCHONN, B. Uso de precipitação estimada pelo satélite TRMM em modelo bidrológico distribuído. 2006. 128 f. Dissertação (Mestrado em Recursos Hídricos e Saneamento Ambiental) - Instituto de Pesquisas Hidráulicas, Universidade Federal do Rio Grande do Sul, Porto Alegre, 2006.

COLLISCHONN, B.; COLLISCHONN, W.; TUCCI, C. E. M. Daily hydrological modeling in the Amazon basin using TRMM rainfall estimates. Journal of Hydrology (Amsterdam), v. 360, n. 1, p. 207-216, 2008. http://dx.doi.org/10.1016/j.jhydrol.2008.07.032.

FALCK, A. S.; MAGGIONI, V.; TOMASELLA, J.; VILA, D. A.; DINIZ, F. L. Propagation of satellite precipitation uncertainties through a distributed hydrologic model: a case study in the Tocantins-Araguaia basin in Brazil. Journal of Hydrology (Amsterdam), v. 527, p. 943-957, 2015. http://dx.doi. org/10.1016/j.jhydrol.2015.05.042.

FENG, D.; ZHENG, Y.; MAO, Y.; ZHANG, A.; WU, B.; LI, J.; TIAN, Y.; WU, X. An integrated hydrological modeling approach for detection and attribution of climatic and human impacts on coastal water resources. Journal of Hydrology (Amsterdam), v. 557, p. 305-320, 2018. http://dx.doi.org/10.1016/j.jhydrol.2017.12.041.

FENSTERSEIFER, C.; ALLASIA, D. G.; PAZ, A. R. Assessment of the TRMM $3 \mathrm{~B} 42$ precipitation product in Southern Brazil. Journal of the American Water Resources Association, v. 52, n. 2, p. 367-375, 2016. http://dx.doi.org/10.1111/1752-1688.12398.

GALDiNO, C. H. P. A.; BRAVO, J. M.; GUTIERREZ, J. C. T. Influência da estimativa da série temporal de chuva na calibração multi-objetivo do modelo IPH II. In: SIMPÓSIO DE RECURSOS HÍDRICOS DO NORDESTE, 12., 2014, Natal. Anais... Porto Alegre: ABRH, 2014.

INMET - INSTITUTO NACIONAL DE METEOROLOGIA. Dados históricos. Brasília, 2017. Available from: <http://www. inmet.gov.br/portal/index.php?r=bdmep/bdmep $>$. Access on: 15 feb. 2017.

JIMÉNEZ, K. Q.; COLLISCHONN, W. Método de combinação de dados de precipitação estimados por satélite e medidos em pluviômetros para a modelagem hidrológica. Revista Brasileira de Recursos Hídricos, v. 20, n. 1, p. 202-217, 2015. http://dx.doi. org/10.21168/rbrh.v20n1.p202-217.

KIDD, C.; KNIVETON, D. R.; TODD, M. C.; BELLERBY, T. J. Satellite rainfall estimation using combined passive microwave and infrared algorithms. Journal of Hydrometeorology, 
v. 4, n. 6, p. 1088-1104, 2003. http:/ / dx.doi.org/10.1175/15257541(2003)004<1088:SREUCP>2.0.CO;2.

KOUCHI, D. H.; ESMAILI, K.; FARIDHOSSEINI, A.; SANAEINEJAD, S. H.; KHALILI, D.; ABBASPOUR, K. C. Sensitivity of calibrated parameters and water resource estimates on different objective functions and optimization algorithms. Water (Basel), v. 9, n. 6, p. 384, 2017. http://dx.doi.org/10.3390/ w9060384.

KUMMEROW, C.; SIMPSON, J.; THIELE, O.; BARNES, W.; CHANG, A. T. C.; STOCKER, E.; ADLER, R. F.; HOU, A.; KAKAR, R.; WENTZ, F.; ASHCROFT, P.; KOZU, T.; HONG, Y.; OKAMOTO, K.; IGUCHI, T.; KUROIWA, H.; IM, E.; HADDAD, Z.; HUFFMAN, G.; FERRIER, B.; OLSON, W. S.; ZIPSER, E.; SMITH, E. A.; WILHEIT, T. T.; NORTH, G.; KRISHNAMURTI, T.; NAKAMURA, K. The STATUS OF THE TROPICAL RAINFALL MEASURING MIssion (TRMM) after two years in orbit. Journal of Applied Meteorology, v. 39, n. 12, p. 1965-1982, 2000. http:/ / dx.doi.org/10.1175/15200450(2001)040<1965:TSOTTR>2.0.CO;2.

LEIVAS, J.; ANDRADE, R.; VICTORIA, D.; TORRESAN, F.; BOLFE, E.; BARROS, T. Monitoramento da Seca Ocorrida em 2012 no Nordeste Brasileiro a Partir dos Dados do SPOTVegetation e TRMM. In: SIMPÓSIO REGIONAL DE GEOPROCESSAMENTO E SENSORIAMENTO REMOTO, 6., 2012, Aracaju. Anais... Aracaju: Embrapa Tabuleiros Costeiros e Universidade Federal de Sergipe, 2012.

LOPES, V. A. R.; FAN, F. M.; COLLISCHONN, W.; PONTES, P. R. M. É possível incluir o efeito do vento em um modelo hidrológico para melhorar a representação de ambientes lagunares? In: SIMPÓSIO BRASILEIRO DE RECURSOS HÍDRICOS, 22., 2017, Florianópolis. Anais... Porto Alegre: ABRH, 2017.

MARCUZZO, F. F. N.; ANDRADE, L. R.; MELO, D. C. R. Métodos de interpolação matemática no mapeamento de chuvas do Estado do Mato Grosso. Revista Brasileira de Geografia Física, v. 4, n. 4, p. 793-804, 2011. http://dx.doi.org/10.26848/rbgf. v4i4.232714.

NASA - NATIONAL AERONAUTICS AND SPACE ADMINISTRATION. TRMM mission comes to an end after 17 years. 2017a. Available from: <http://pmm.nasa.gov/trmm/ mission-end $>$. Access on: 25 july $2017 \mathrm{a}$.

NASA - NATIONAL AERONAUTICS AND SPACE ADMINISTRATION. Mission update 6/16/2015. 2017b. Available from: < http://pmm.nasa.gov/trmm>. Access on: 24 sept. 2017 b.

NIKOLOPOUlOS, E. I.; ANAGNOSTOU, E. N.; BORGA, M. Using high-resolution satellite rainfall products to simulate a major flash flood event in northern Italy. Journal of Hydrometeorology, v. 14, n. 1, p. 171-185, 2013. http://dx.doi.org/10.1175/JHM-D-12-09.1.
NIKOLOPOULOS, E. I.; ANAGNOSTOU, E. N.; HOSSAIN, F.; GEBREMICHAEL, M.; BORGA, M. Understanding the scale relationships of uncertainty propagation of satellite rainfall through a distributed hydrologic model. Journal of Hydrometeorology, v. 11, n. 2, p. 520-532, 2010. http://dx.doi.org/10.1175/2009JHM1169.1.

PAULA, S. C. Precipitação estimada por satélite para uso em modelo concentrado chuva-vazão aplicado em diferentes escalas de bacias. 2015. 168 f. Dissertação (Mestrado em Engenharia Civil) - Universidade Federal de Santa Maria, Santa Maria, 2015.

PEREIRA, G.; SILVA, M. E. S.; MORAES, E. C.; CARDOZO, F. S. Avaliação dos dados de precipitação estimados pelo satélite TRMM para o Brasil. Revista Brasileira de Recursos Hidricos, v. 18, n. 3, p. 139-148, 2013. http://dx.doi.org/10.21168/rbrh.v18n3. p139-148.

SALIO, P.; HOBOUCHIAN, M. P.; GARCÍA SKABAR, Y.; VILA, D. Evaluation of high-resolution satellite precipitation estimates over southern South America using a dense rain gauge network. Atmospheric Research, v. 163, p. 146-161, 2015. http:// dx.doi.org/10.1016/j.atmosres.2014.11.017.

SANTHI, C.; ARNOLD, J. G.; WILLIAMS, J. R.; DUGAS, W. A.; SRINIVASAN, R.; HAUCK, L. M. Validation of the swat model on a large river basin with point and nonpoint sources. Journal of the American Water Resources Association, v. 37, n. 5, p. 1169-1188, 2001. http://dx.doi.org/10.1111/j.1752-1688.2001. tb03630.x.

SCHIAVO BERNARDI, E.; ALLASIA, D.; BASSO, R.; FREITAS FERREIRA, P.; TASSI, R. TRMM rainfall estimative coupled with Bell (1969) methodology for extreme rainfall characterization. Proceedings of the International Association of Hydrological Sciences, v. 369, p. 163-168, 2015. http://dx.doi. org/10.5194/piahs-369-163-2015.

SEMA - SECRETARIA DO AMBIENTE E DESENVOLVIMENTO SUSTENTÁVEL. Relatório Anual sobre a Situação dos Recursos Hidricos no Estado do Rio Grande do Sul-Ano 2009/2010. Porto Alegre, 2012.

SILANS, A. D.; ALMEIDA, C. D. N.; PORTO, R. D. Q. Impacto da incerteza na representatividade da repartição espacial da precipitação sobre os hidrogramas e as curvas de permanência obtidos de um modelo chuva-vazão distribuído. Revista Brasileira de Recursos Hídricos, v. 14, n. 2, p. 59-71, 2009. http://dx.doi. org/10.21168/rbrh.v14n2.p59-71.

SOARES, A.; PAZ, A.; PICCILLI, D. Avaliação das estimativas de chuva do satélite TRMM no Estado da Paraíba. Revista Brasileira de Recursos Hídricos, v. 21, n. 2, p. 288-299, 2016. http://dx.doi. org/10.21168/rbrh.v21n2.p288-299.

TUCCI, C. E. M. Hidrologia: ciência e aplicação. 4. ed. Porto Alegre: Ed. ABRH, Editora da UFRGS, 2013. 
VAN LIEW, M. W.; ARNOLD, J. G.; GARBRECHT, J. D. Hydrologic simulation on agricultural watersheds: choosing between two models. Transactions of the ASAE. American Society of Agricultural Engineers, v. 46, n. 6, p. 1539-1551, 2003. http:// dx.doi.org/10.13031/2013.15643.

VIANA, D. R.; FERREIRA, N. J.; CONFORTE, J. C. Avaliação das estimativas de precipitação 3B42 e 3B43 do satélite TRMM na Região Sul do Brasil. In: CONGRESSO BRASILEIRO DE METEOROLOGIA, 16., 2010, Belém, PA. Anais... São Paulo: SBMET, 2010.

VIANA, J. F. S.; MONTENEGRO, S. M. G. L.; SILVA, B. B.; DA SILVA, R. M.; SOUSA, W. D. S. Modelagem hidrológica da Bacia Hidrográfica do Rio Pirapama-PE utilizando o modelo SWAT. Journal of Environmental Analysis and Progress, v. 3, n. 1, p. 155-172, 2018. http://dx.doi.org/10.24221/ jeap.3.1.2018.1709.155-172.

WU, H.; ADLER, R. F.; TIAN, Y.; GU, G.; HUFFMAN, G. J. Evaluation of quantitative precipitation estimations through hydrological modeling in IFloodS river basins. Journal of
Hydrometeorology, v. 18, n. 2, p. 529-553, 2017. http://dx.doi. org/10.1175/JHM-D-15-0149.1.

\section{Authors contributions}

Stefany Correia de Paula: Developed the idea for the study, bibliographical research, design of experiments, modeling, data analysis, discussion and interpretation of the results, writing and preparation of figures and tables, manuscript submission.

Rutineia Tassi: Developed the idea for the study as well as its design, modeling for data treatment, discussion and interpretation of the results, writing and paper review.

Daniel Gustavo Allasia Piccilli: Developed the idea for the study, discussion of the results, paper review.

Francisco Lorenzini Neto: Discussion and interpretation of the results, paper review. 